\title{
THE EFFECT OF ENERGY CONSERVATION ON ENVIRONMENTAL EMISSIONS: UTILITY, RESIDENTIAL, AND COMMERCIAL SECTORS
}

Paul D. Raskin and Richard A. Rosen

September 1977

Prepared by the

ENERGY SYSTEMS RESEARCH GROUP, INC.

ALBANY, NEW YORK

For the

OFFICE OF ENVIRONMENTAL POLICY

NATIONAL CENTER FOR ANALYSIS OF ENERGY SYSTEMS

BROOKHAVEN NATIONAL LABORATORY ASSOCIATED UNIVERSITIES, INC.

UNDER CONTRACT NO. EY.76-C.02.0016 WITH THE

OFFICE OF TECHNOLOGY IMPACTS/ASEV

UNITED STATES DEPARTMENT OF ENERGY 


\section{DISCLAIMER}

This report was prepared as an account of work sponsored by an agency of the United States Government. Neither the United States Government nor any agency Thereof, nor any of their employees, makes any warranty, express or implied, or assumes any legal liability or responsibility for the accuracy, completeness, or usefulness of any information, apparatus, product, or process disclosed, or represents that its use would not infringe privately owned rights. Reference herein to any specific commercial product, process, or service by trade name, trademark, manufacturer, or otherwise does not necessarily constitute or imply its endorsement, recommendation, or favoring by the United States Government or any agency thereof. The views and opinions of authors expressed herein do not necessarily state or reflect those of the United States Government or any agency thereof. 


\section{DISCLAIMER}

Portions of this document may be illegible in electronic image products. Images are produced from the best available original document. 


\title{
THE EFFECT OF ENERGY \\ CONSERVATION ON ENVIRONMENTAL EMISSIONS: UTILITY, RESIDENTIAL, AND COMMERCIAL SECTORS
}

\author{
Paul D. Raskin and Richard A. Rosen
}

September 1977

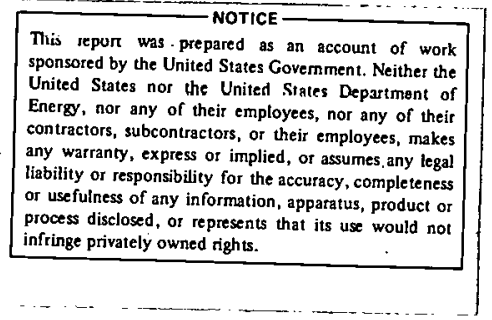

Prepared by the

ENERGY. SYSTEMS RESEARCH GROUP, INC.

ALBANY, NEW YORK

For the

OFFICE OF ENVIRONMENTAL POLICY.

NATIONAL CENTER FOR ANALYSIS OF ENERGY SYSTEMS

BROOKHAVEN NATIONAL LABORATORY

UPTON, NEW YORK 11973 


\section{NOTICE}

This report was prepared as an account of work sponsored by the United States Government. Neither the United States nor the United States Department of Energy (DOE), nor any of their employees, nor any of their contractors, subcontractors, or their employees, makes any warranty, express or implied, or assumes any legal liability or responsibility for the accuracy, completeness or usefulness of any information, apparatus, product or process disclosed, or represents that its use would not infringe privately owned rights.

Printed in the United States of America

$$
\text { Available from }
$$

National Technical Information Service

U.S. Department of Commerce

5285 Port Royal Road

Springfield, VA 22161

Price: Printed Copy $\$ 4.50 ;$ Microfiche $\$ 3.00$ 
I. Introduction. . . . . . . . . . . . . . 1

II. Utility Emissions . . . . . . . . . . . . . 2

A. Energy Demands by Scenario. . . . . . . . . 4

B. Emission Coefficients ............ 11

C. Emission Intensities. . . . . . . . . . 14

D. Total Emissions .............. 17

III. Residential and Commercial Emissions. . . . . . . 19

A. Energy Demand by Scenario ........... 19

B. Emission Coefficients ............. 24

C. Emissions by End Use. . . . . . . . . . 29

D. Total Emissions .............. 29

References. . . . . . . . . . . . . . 34 


\section{FIGURES}

1: Reference energy system, year 1985: SF-2. . . . . . 4

2. Reference energy syster, year 2000: SF-2. . . .... 5

3. Reference energy system, year 1985: NEP . . . . . 6

4. Reference energy system, year 2000: NEP. ....... 7

\section{TABLES}

1. Electric utility sector intermediate energy forms

for ERDA scenarios in 1972, 1985, and 2000 . . . . 8

2. Electric utility sector energy demands in CONAES

scenarios for year 2000. . . . . . . . . . . . 8

3. Internal use of energy by the $\epsilon$ nergy-producing

Industries, Scenario B........ . . 8

4. Electric utility sector: intermedlate energy

forms and energy resources for the CONAES

scenarios in 2000. . . . . . . . . . . . . . 10

5. CONAES energy resource totals, 2000. . . . . . . . 10

6. Intermediate energy forms burned by electric utilities................ 10

7. Utility pollutants considered. . . . . . . . . 12

8. Utility emission factors . . . . . . . . . . 12

9. Average fuel characteristics, utility sector . . . . 12

10. Electric utility emission coefficients, uncontrolled case. . . . . . . . . . . . . 13

11. Electric utility emission coefficients, controlled case. . . . . . . . . . . . . . 13

12. Fraction of plants, uncontrolled . . . . . . . 15

13. Base year emissions matrix . . . . . . . . . 15 
TABLES (continued)

14. Scenario A 1985 emissions matrix. . . . . . . . 15

15. Scenario B..1985 emissions matrix. . . . . . . . . 16

16. NEP 1985 emisstons matrix . . . . . . . . . . . 16

17. SF-2 1985 emissions matrix. . . . . . . . . . 16

18. Emission intensities by scenario. . . . . . . . . . 18

19. Total utility emissions . . . . . . . . . . . 18

20. Base year commercial-residential fuel breakdowns. . . 22

21. Fractional distributions of fuel. . . . . . . . . 22

22. Aggregate fuel mix by scenario. . . . . . . . . 22

23. Household and commercial floorspace assumptions . . . 23

24. End-use energy intensities. . . . . . . . . . 23

25. Commercial sector fuel breakdown. . . . . . . . . 25

26. Residential sector fuel breakdown . . . . . . . . 26

27. Boiler emission factors, commercial sector. . . . . . 27

28. Boiler emission factors, residential sector . . . . . 27

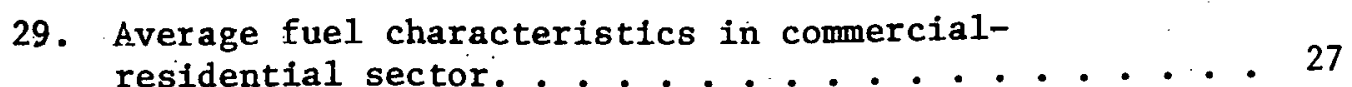

30. Boiler emission matrix, commercial sector . . . . . 28

31. Boiler emission matrix, residential sector. . . . . 28

32. Emission matrix correction factors. . . . . . . 28

33. Computational procedure for commercial end-use emissions . . . . . . . . . . . 30

34. Computational procedure for residential end-use emissions . . . . . . . . . . . 30

35. Emissions by end use, commercial sector . . . . . . 31

36. Emissions by end use, residential sector. . . . . . 32 


\section{TABLES (continued)}

37. Commercial emission totals. . . . . . . . . . 33

38. Residential emission totals . . . . . . . . . 33

39. Total commercial-residential emissions. . . . . . . 33 
Environmental emissions in the utility, residential, and commercial sectors are estimated for four U.S. energy system scenarios and two future target years. Total utility emissions are estimated by specifying; for each scenario and year, total energy demands, fuel mixes, generating technologies, and air pollution control levels. In the residential and commerical sectors energy end-use requirements for space heating and cooling are determined and combined with end-use specific emission coefficients to calculate total emissions. The analyses show: that emissions do not vary significantly among scenarios even though total energy use differs by as much as 45 quads. Low-energy demand scenario emissions increase relative to high-energy demand scenarios principally because of the relative increase in coal usage. Utility sector emissions are greater than residential and commercial sector … ènissions. 


\section{INTRODUCTION}

In this study, environmental emissions in the utility, commercial, and residential sectors are evaluated for four energy system scenarios and two future target years. This study is an extension of an analogous study of the industrial sector, ${ }^{1}$ also by Energy Systems Research Group, Inc., and is a contribution to the assessment by the BNL Office of Environmental Policy (OEP) of national environmental implications of possible transitions toward conservation in energy utilization patterns. The four scenarios are CONAES* scenario A, CONAES scenario B, the National Energy Plan scenario, and ERDA's scenario SF-2 (abbreviated A, B, NEP, and SF-2, respectively, throughout this report). The years selected for analysis are 1985 and 2000.

Section II focuses on emissions from the electric utility sector. For each scenario, total emissions are computed for ten air and water pollutants. This is done by specifying, for each scenario and year, total energy demands, fuel mixes, generating technology assumptions, and pollution control levels, and using these values, together with emission factor data, as the basis for the computation.

Section III is concerned with the commercial and residential sectors. Since, in the scenarios, energy flows are insufficiently disaggregated, it is first necessary to develop a consistent basis for separating energy demands by end-use in each sector. Then, emission matrices are developed for each end-use for five major air pollutants (water pollutants being negligible).

\footnotetext{
* National Academy of Sciences Committee on Nuclear and Alternative Energy Strategies.
} 


\section{UTILITY EMISSIONS}

Four factors contribute to the dependence of utility sector emissions on explicit or implied scenario-specific assumptions: (1) the magnitude of demand for electricity, (2) the $\mathrm{mtx}$ of fuels to central generating stations, (3) the breakdown of peaking versus base-load facilities, and (4) the degree of penetration of pollution abatement technology. Each of these factors plays a role in determining final emissions. The magnitude of demand for electricity varies widely over the scenarios analyzed because of differences in the assumptions about the growth rate of end-use demand and about improvements in energy conversion effictency. The fractional breakdown of intermediate energy forms also varies over the scenarios. One key parameter here is the assumed impact of polfcies to induce accelerated growth in the use of coal in the utility sector. Disaggregated data on the fuel going to peak-power turbines on the one hand, and to base-load boilers on the other, is important because different emission characteristics are involved. Finally, emission control levels are sensitive to electric energy growth rates since standards affect new and existing facilities differentially.

The calculation of emissions involves the following major steps: (1) specification of scenario assumptions on electricity production disaggregated by fuel and generating technology, (2) designation of emission matrices that incorporate control assumptions and give emfssion levels for 10 pollutants (5 in air and 5 in water) and for electric power production systems using four types of fossil fuel, and (3) multiplication of the energy breakdowns and the emission matrices to obtain emission estimates. 
The analysis in this study is restricted to fossil-fuel-fired electric plants. It does not include, e.g., radiation emissions from nuclear power plants or possible emissions from nonconventional sources such as solar electricity generation. Emissions associated with the cogeneration of electricity as an offshoot of industrial processes is treated in the companion study. ${ }^{1}$

\section{A. Energy Demands by Scenario}

The energy requirements for each sector are reported quite differently for the ERDA and CONAES scenarios. For ERDA, all flows of energy to the sector are explicit in the Reference Energy Systems (RESs) for 1972, 1985, and 2000 (see Figures 1 to 4 ). These include separate flows for oil and gas to steam boilers, and for oil and gas to gas turbines for peaking power. Since the emissions from the two technologies differ, it is important to maintain this level of detail. The ERDA RESs are also completely explicit about the individual contributions to be made by the new technologies using wood, solar, and geothermal energy for generating electricity. The totals for all energy sources are given in Table 1, which includes transmission losses and net electricity consumed by end users. The ERDA scenarios are characterized by a strong shift toward coal and nuclear fuels and away from oil and gas.

For the CONAES scenarios, much less information for the electric utility sector has been explicityly provided. The studies on the industrial sector $^{1}$ provided data on how much electricity that sector consumed. The gross electrical consumption of the residential and commercial sectors was available explicitly ${ }^{7}$ in CONAES Tables III-12 and III-29. Since one of 




Figure 1. Reference energy system, year 1985-SF-2. 


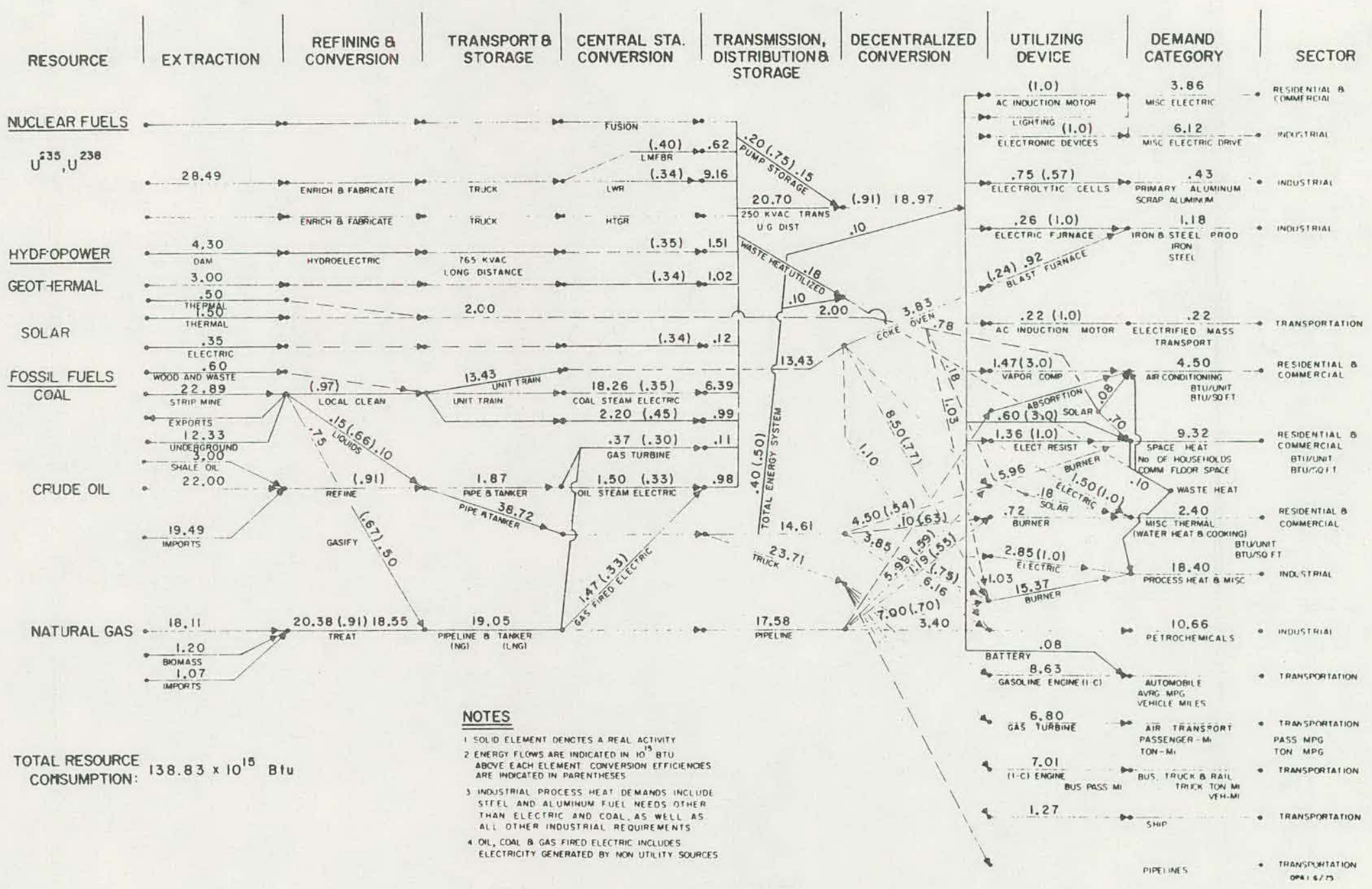

F1gure 2. Reference energy system, year 2000 SF-2. 


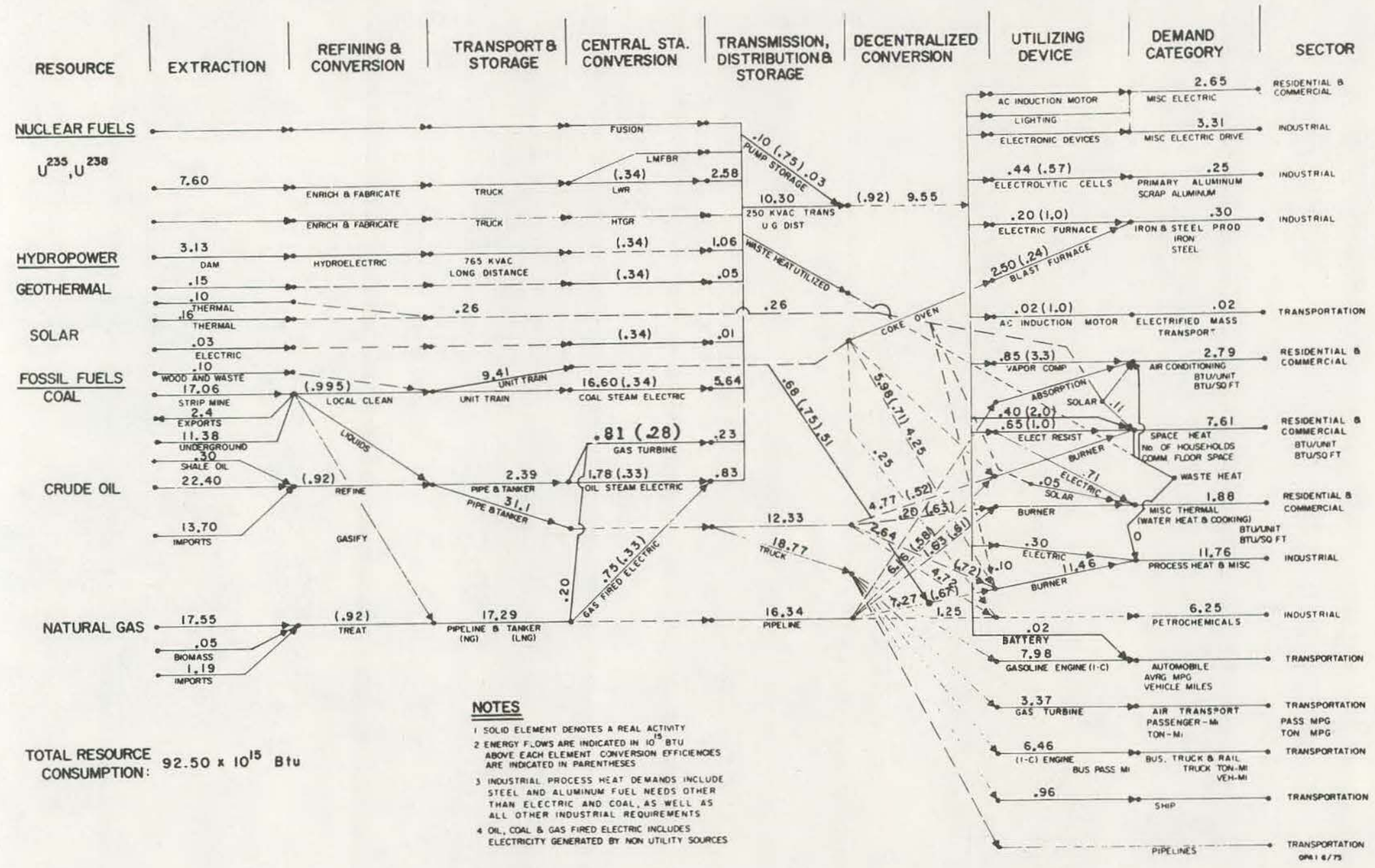

Figure 3. Reference energy system, year 1985 NEP. 


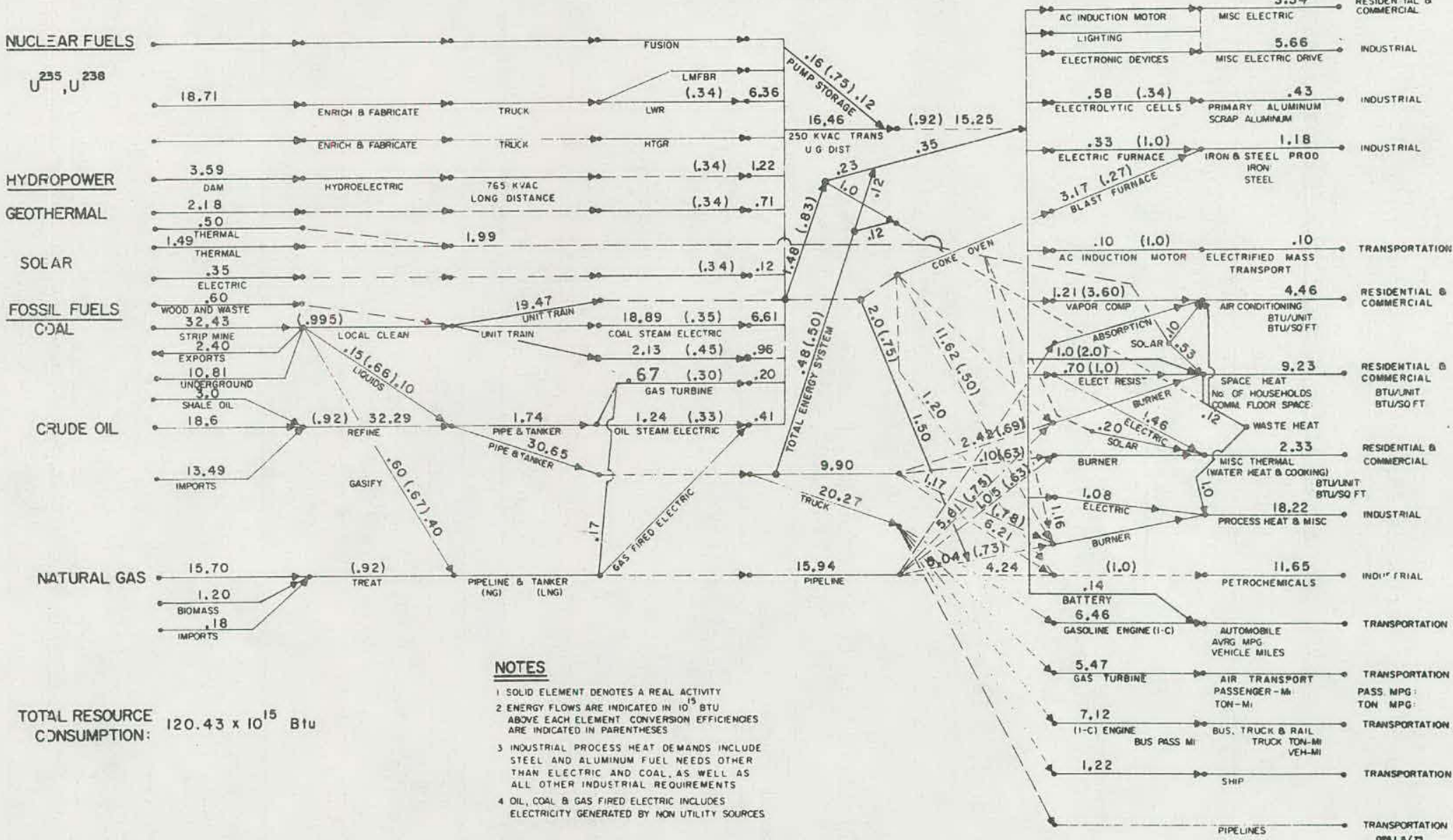

Figure 4. Reference energy system, year 2000 NEP. 


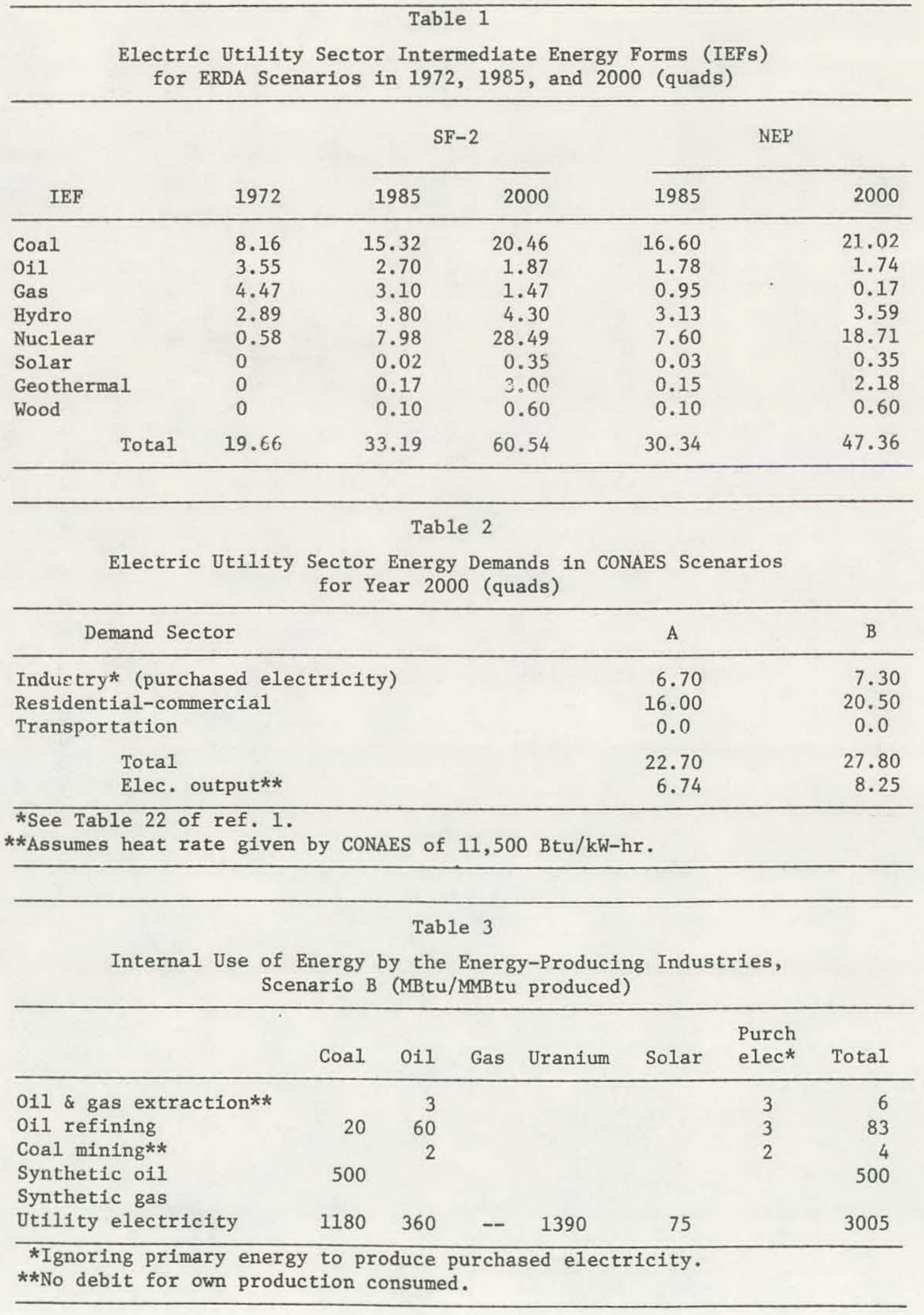


the assumptions of this study was negligible use of electrictty by the transportation sector, simple addition of the above totals (see Table 2) gave the total gross electricity demand. The fuel mix percentages for B were derived from CONAES Table V-4, reproduced here as Table 3. Since CONAES provided no explicit data for the utility sector for scenario A, the proportions were assumed to be the same as for scenarto B.

The resulting proportions for the year 2000 are in terms of intermediate energy forms (IEFs) to the utility sector: coal $39.3 \%$, ofl $12.0 \%$, gas $0 \%$, nuclear and hydro $46.2 \%$, and solar $2.5 \%$. Applied to these fuel mixes are fuel resource to IEF 1 osses of $3.5 \%$ for coal and $10 \%$ for oil, as in the ERDA scenarios. The resulting demands for IEFs and resources for 2000 are listed in Table 4. The sectoral energy consumptions assumed in this project can be cross-checked by comparing total energy consumption with the totals assumed in the CONAES study. ${ }^{7}$ The comparison given in Table 5 demonstrates that the disaggregations used here are generally consistent with the CONAES global assumptions.

Since the CONAES scenarios included no explicit assumption about the extent of gas turbine use for peaking, and since this use is important in calculating emissions, it was assumed that these scenarios; being strongly conservation oriented, incorporate intensive load-management and peakleveling practicies as well as shifts to alternative fuels. Thus, for. future years, it was assumed that base year gas turbines were phased out at an annual retirement rate based on 30-year 1ifetimes. The total IEFs for all scenarios that contribute to fossil fuel utility sector emissions are summarized, by technology, in Table 6 . 


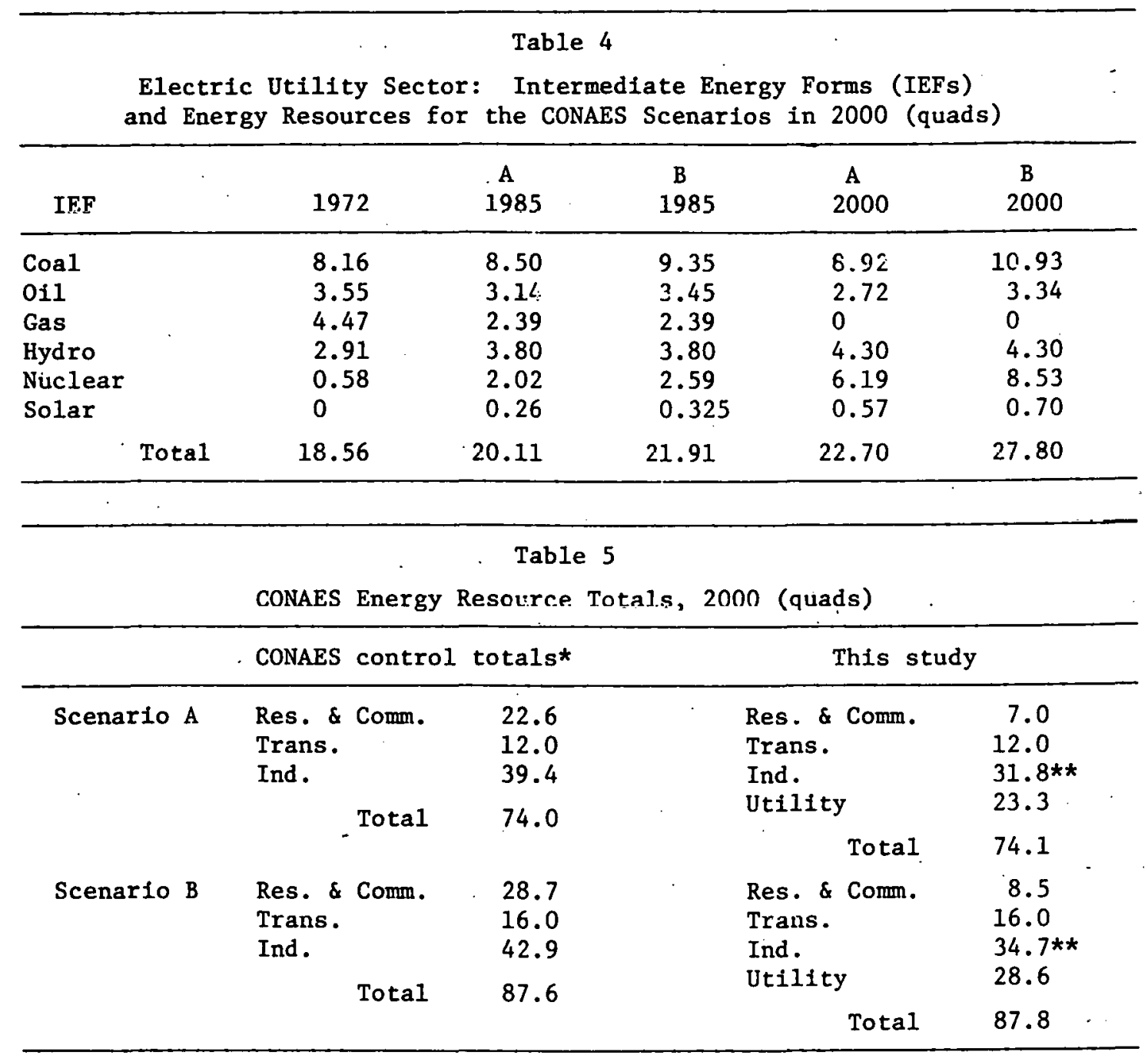

*Utility consumption allotted to each sector separately. **From ref. 1, with resource losses included at $8 \%$ rate.

Table 6

Intermediate Energy Forms Burned by Electric Utilities (quads)

\begin{tabular}{|c|c|c|c|c|c|c|c|c|}
\hline & & & \multicolumn{3}{|c|}{ Boilers } & \multicolumn{3}{|c|}{ Turbines } \\
\hline & & & Coal & 011 & Nat.gas & Wood & oil & Nat.gas \\
\hline \multirow{5}{*}{$\begin{array}{l}\text { 1972: } \\
\text { 1985: }\end{array}$} & Base & & 8.16 & 3.27 & 4.30 & 0. & 0.28 & 0.17 \\
\hline & A & & 8.50 & 2.85 & 2.39 & 0 & 0.29 & 0 \\
\hline & B & & 9.35 & 3.16 & 2.39 & 0 & 0.29 & 0 \\
\hline & NEP & & 16.60 & 1.78 & 0.75 & 0.10 & 0.61 & 0.20 \\
\hline & SF-2 & & 15.32 & 2.09 & 3.10 & 0.10 & 0.61 & 0 \\
\hline \multirow[t]{4}{*}{$2000:^{\circ}$} & A & & 8.92 & 2.55 & 0 & 0 & 0.17 & 0 \\
\hline & B & & 10.93 & 3.17 & 0 & 0 & 0.17 & $0^{\circ}$ \\
\hline & NEP & & 21.02 & 1.24 & 0 & 0.60 & 0.50 & 0.17 \\
\hline & $S F-2$ & & 20.46 & 1.50 & 1.47 & 0.60 & 0.37 & 0 \\
\hline
\end{tabular}




\section{B. Emission Coefficients}

Emission coefficients were developed for the fossil fuel utility sector for each scenario-year. The pollutants considered are listed in Table 7 .

The starting point for the calculation of emission coefficients (in units of short tons of pollutant per $10^{12}$ Btu of fuel) are the air emission factors (Table 8), which give emissions for uncontrolled facilities in pounds of pollutant per physical unit of fuel. The average physical characteristics of the fuels in the utility sector included in this study are given in Table 9 .

Once the level of emission control is specified, the emission factors and average fuel characteristic data can be combined to give the emission coefficients. Two sets of coefficients are developed as in ref. 3: an "uncontrolled" case and a "controlled" case. The array of emission coefficients for both air and water pollutants is given for the two cases in Tables 10 and 11. Control levels are those used by Hittman ${ }^{3}$ except where noted. The discrepancies are attributable either to use, in the previous work, of now outdated raw data from the earlier edition of the EPA report ${ }^{2}$ or' to computational errors.

The next step is to specify the fractional breakdown of controlled and uncontrolled plants. The scenario-specific emission coefficients will then be appropriately weighted averages of the emission matrices in Tables 10 and 11. The fractions of central electric plants that are uncontrolled are given as 0.775 for 1972 and 0 for 2000 by Beller. ${ }^{6}$. The fraction uncontrolled for 1985 was computed by linear extrapolation of the 1972 value to zero in 2000: if, for the ath scenario, total energy consumption in the utility 


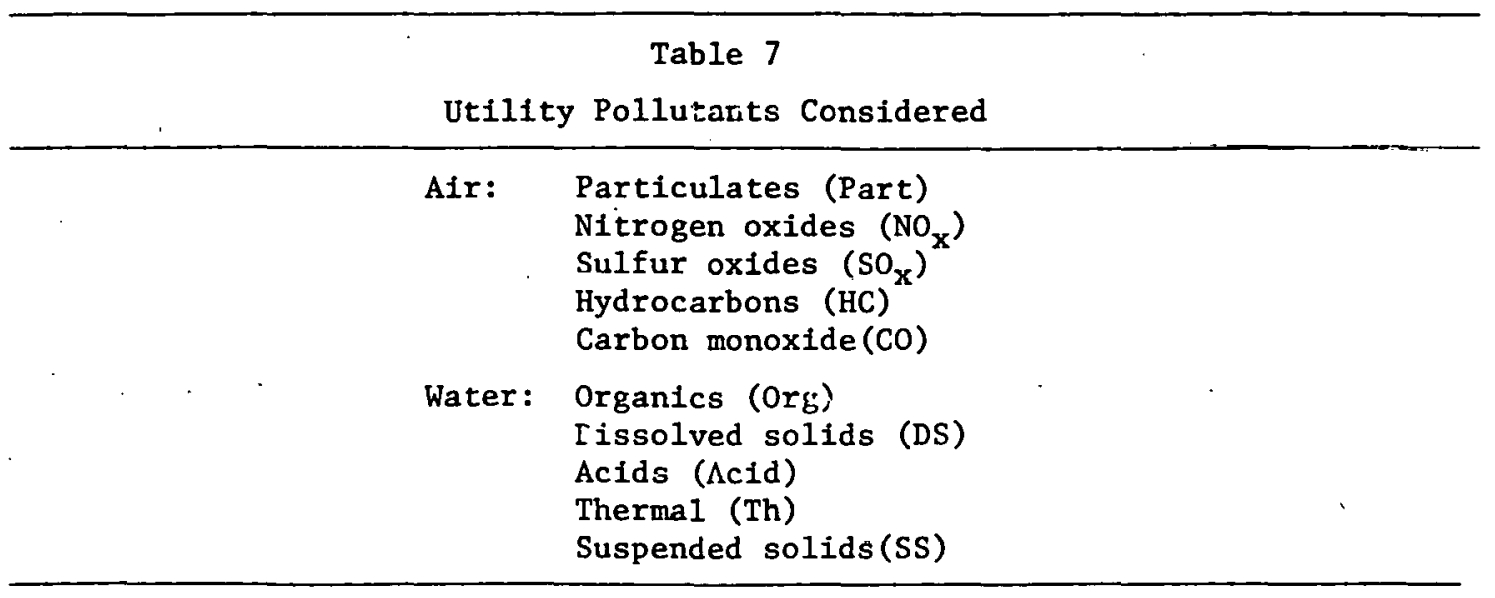

Table 8

Utility Emission Factors (1b/physical fuel unit) (from ref. 2)

\begin{tabular}{|c|c|c|c|c|c|c|c|}
\hline & Fue1 & Unit & Part* & $\mathrm{NO}_{\mathrm{x}}$ & $\mathrm{SO}_{\mathrm{X}} \star \star *$ & $\mathrm{HC}$ & $\mathrm{Co}$ \\
\hline Boilers: & $\begin{array}{l}\text { Coal } \\
\text { 0i1 } \\
\text { Nat. gas } \\
\text { Wood }\end{array}$ & $\begin{array}{ll} & \text { ton } \\
10^{3} & \mathrm{gal} \\
10^{6} & \mathrm{ft}^{3} \\
& \text { ton }\end{array}$ & $\begin{array}{r}16 A \\
8 \\
10 \\
10\end{array}$ & $\begin{array}{r}18 \\
105 \\
700 \\
10\end{array}$ & $\begin{array}{r}38 \mathrm{~S} \\
1.59 \mathrm{~S} \\
0.6 \\
1.5\end{array}$ & $\begin{array}{r}0.3 \\
2 \\
1 \\
35\end{array}$ & $\begin{array}{r}1 \\
3 \\
17 \\
30\end{array}$ \\
\hline Turbines: & $\begin{array}{l}0 i 1 \\
\text { Nat. gas }\end{array}$ & $\begin{array}{ll}10^{3} & \mathrm{gal} \\
10^{6} & \mathrm{ft}^{3}\end{array}$ & $\begin{array}{r}5 \\
14\end{array}$ & $\begin{array}{r}67.8 \\
413\end{array}$ & $\begin{array}{l}140 \mathrm{~S} \\
940 \mathrm{~S}\end{array}$ & $\begin{array}{r}5.57 \\
42\end{array}$ & $\begin{array}{r}15.4 \\
115\end{array}$ \\
\hline
\end{tabular}

Table 9

Average Fuel Characteristics, Utility Sector (from ref. 3)

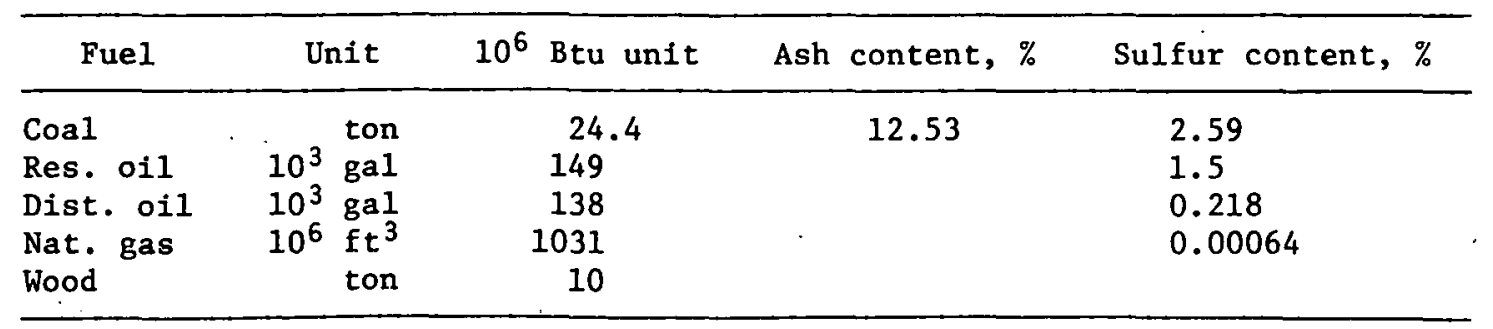


Table 10

Electric Ut1lity Emission Coefficients, Uncontrolled Case (short ton $/ 10^{12} \mathrm{Btu}$ )

\begin{tabular}{|c|c|c|c|c|c|c|c|c|c|c|}
\hline & Part & $\mathrm{NO}_{\mathrm{x}}$ & $\mathrm{SO}_{\mathrm{x}}$ & $\mathrm{HC}$ & $\mathrm{CO}$ & Org & DS & Acid & $\begin{array}{c}\text { Th } \\
10^{12} \mathrm{Btu}\end{array}$ & LS \\
\hline \multicolumn{11}{|l|}{ Boiler: } \\
\hline Coa1 & 82.2 & 369 & 2020 & 6.15 & 20.5 & 2.71 & 58.1 & 25.7 & 0.528 & 6.84 \\
\hline $0 i 1$ & 27.2 & 357 & $811 *$ & 6.81 & $10.2 * *$ & 0.0155 & 7.44 & -- & 0.526 & 0.709 \\
\hline Nat. gas & $4.85 * *$ & 191. & 0.293 & $0.485 * *$ & $8.25 * \star$ & 0.0155 & $3.4 \mathrm{C}$ & -- & 0.526 & 0.709 \\
\hline \multicolumn{11}{|l|}{ Turbine: } \\
\hline 011 & 18.0 & 244 & 113 & 20.1 & 55.5 & -- & -- & -- & -- & -- \\
\hline Nat. gas & 6.80 & 201 & 0.293 & 20.4 & 56.0 & $\cdot-$ & - & -- & -- & -- \\
\hline
\end{tabular}

\section{$\therefore \quad$ Table 11}

Electric Utility Emission Coefficients, Controlled Case (short ton/1012 Btu)

Values are based on EPA emissions 1imitations (see ref. 4 for boilers and. ref. 5 for turbines). Uncontrolled values are used for the base year (BY) because the new source performance standards for turbines (ref. 5) were not given because they are negligible.

\begin{tabular}{|c|c|c|c|c|c|c|c|}
\hline & Part & No $x$ & $\mathrm{So}_{x}$ & $\mathrm{HC}$ & $\mathrm{CO}$ & Org & DS \\
\hline \multicolumn{8}{|l|}{ Boiler: } \\
\hline Coa1 & 20.6 & 350 & 202 & 6.15 & 20.5 & 0.00302 & 18.2 \\
\hline $0 i 1$ & 27.2 & $150^{\circ}$ & 320 & 6.81 & 10.2 & 0.00302 & \\
\hline Nat. gas & 4.85 & 100 & 0.293 & 0.485 & 8.25 & 0.00302 & \\
\hline Wood** & 2.5 & 350 & 7.5 & 180 & 150 & 0.00302 & \\
\hline \multicolumn{8}{|l|}{ Turbine: } \\
\hline 011 & 18.0 & $\begin{array}{c}244 \text { (BY) } \\
73.2\end{array}$ & $\begin{array}{c}113 \text { (BY) } \\
70.0\end{array}$ & 20.1 & 55.5 & - & \\
\hline Nat. gas & 6.80 & $\begin{array}{l}201 .(\mathrm{BY}) \\
60.3\end{array}$ & 0.293 & 20.4 & 56.0 & -- & \\
\hline
\end{tabular}


sector is $E^{a}$, then the fraction uncontrolled, $f^{a}$, in 1985 is

$$
\mathrm{f}^{\mathrm{a}}=(15 / 28)(0.775) \mathrm{E}_{1972} / \mathrm{E}^{\mathrm{a}}
$$

The results are summarized in Table 12 .

The appropriate emission matrix for each scenario can now be computed.

Let $\begin{aligned} & e_{i j}^{a}=\text { the emission of pollutant } j \text { in ton } / 10^{12} \text { Btu due to fuel/ } \\ & \text { combustion process } i \text { in scenario } a,\end{aligned}$

$u_{i j}^{a}$ - the corresponding "uncontrolled" matrix,

$c_{i j}^{a}=$ the corresponding "controlled" matrix, and

$\mathrm{f}^{\mathrm{a}}=$ the fraction "uncontrolled" in scenario $a$.

Then

$$
e_{i j}^{a}=f^{a} u_{i j}^{a}+\left(1-f^{a}\right) c_{i j}^{a}
$$

Since, for the year 2000, it has been assumed that all plants are at the "controlled" level, $f^{a}=0$ and therefore $e_{i j}^{a}=c_{i j}^{a}$ for a11 scenarios in that year. This matrix is given in Table 11 . The values of $e_{i j}^{a}$ for the five other cases (base year and four 1985 scenarios) are presented in Tables 13 to 17 .

\section{Emission Intensities}

The emission matrices give the quantity of each pollutant emitted per unit fuel input for both boiler and turbine electric generating technologies. The matrix for each scenario embodies the level of emission control. In this section, emissions per kilowatt-hour generated are calculated for all scenario-years under consideration. Let $e_{i j}^{a}$ be the emissions matrix 
Table 12

Fraction of Plans Uncontrolled, 1985



Table 13

Base Year Emissions Matrix (short ton/10 $12 \mathrm{Btu}$ )

(No wood is burned in the base year)

\begin{tabular}{|c|c|c|c|c|c|c|c|c|c|c|}
\hline & Part & $\mathrm{NO}_{\mathbf{x}}$ & $\mathrm{SO}_{\mathbf{x}}$ & $\mathrm{HC}$ & $\mathrm{CO}$ & Org & DS & Acid & $\begin{array}{c}\text { Th } \\
\left(10^{12} \mathrm{Btu}\right)\end{array}$ & SS \\
\hline \multicolumn{11}{|l|}{ Boiler: } \\
\hline Coal & 68.3 & 364 & 1610 & 6.15 & 20.5 & 2.10 & 49.1 & 19.9 & 0.409 & 5.30 \\
\hline $0 i 1$ & 27.2 & 310 & 700 & 6.81 & 10.2 & 0.0126 & 6.53 & 0 & 0.407 & 0.549 \\
\hline Nat. gas & 4.85 & 170 & 0.293 & 0.485 & 8.25 & 0.0126 & 3.40 . & 0 & 0.407 & 0.549 \\
\hline \multicolumn{11}{|l|}{ Turbine: } \\
\hline $0 i 1$ & 18 & 244 & 113 & 20.1 & 55.5 & 0 & 0 & 0 & 0 & 0 \\
\hline Nat. gas & 6.8 & 201 & 0.293 & 20.4 & 56 & 0 & 0 & 0 & 0 & 0 \\
\hline
\end{tabular}

Table 1.4

Scenario A 1985 Emissions Matrix (short ton/10 $12 \mathrm{Btu}$ )

\begin{tabular}{|c|c|c|c|c|c|c|c|c|c|c|}
\hline . & Part & $\mathrm{NO}_{\mathbf{x}}$ & $\mathrm{SO}_{x}$ & $\mathrm{HC}$ & $\mathrm{CO}$ & Org & DS & Acid & $\begin{array}{c}\text { Tht* } \\
\left(10^{12} \mathrm{Btu}\right)\end{array}$ & SS \\
\hline \multicolumn{11}{|l|}{ Boiler: } \\
\hline Coal & 50.1 & 359 & 1072 & 6.15 & 20.5 & 1.29 & 37.3 & 12.3 & 0.252 & 3.27 \\
\hline $0 i 1$ & 27.2 & 249 & 555 & 6.81 & 10.2 & 0.00899 & 5.33 & 0 & 0.251 & 0.339 \\
\hline Nat. gas & 4.85 & $143^{\circ}$ & 0.293 & 0.485 & 8.25 & 0.00899 & 3.40 & 0 & 0.251 & 0.339 \\
\hline Wood* & 1.30 & 182 & 3.90 & 93.7 & 78.1 & 0.00157 & $9.48^{\circ}$ & 0 & 0 & 0 \\
\hline \multicolumn{11}{|l|}{ Turbine: } \\
\hline 011 & 18 & 155 & 90.6 & 20.1 & 55.5 & 0 & 0 & 0 & 0 & 0 \\
\hline Nat. gas & 6.8 & 127 & 0.293 & 20.4 & 56.0 & 0 & 0 & 0 & 0 & 0 \\
\hline
\end{tabular}


Table 15

Scenario B 1985 Emissions Matrix (short ton/10 12 Btu)

\begin{tabular}{|c|c|c|c|c|c|c|c|c|c|c|}
\hline & Part & $\mathrm{NO}_{x}$ & $\mathrm{SO}_{x}$ & $\mathrm{HC}$ & $\mathrm{CO}$ & Org & DS & Acid & $\begin{array}{c}\text { Th } \\
\left(10^{12} \text { Btu }\right)\end{array}$ & SS \\
\hline Boiler: & & & & & & & & & & \\
\hline $\begin{array}{l}\text { Coal } \\
\text { Oil } \\
\text { Nat. gas } \\
\text { Wood* }\end{array}$ & $\begin{array}{c}47.8 \\
27.2 \\
4.85 \\
1.39\end{array}$ & $\begin{array}{l}358 \\
241 \\
140 \\
195\end{array}$ & $\begin{array}{c}1005 \\
537 \\
0.293 \\
4.18\end{array}$ & $\begin{array}{c}6.15 \\
6.81 \\
0.485 \\
100\end{array}$ & $\begin{array}{c}20.5 \\
10.2 \\
8.25 \\
83.7\end{array}$ & $\begin{array}{l}1.20 \\
0.00853 \\
0.00853 \\
0.00168\end{array}$ & $\begin{array}{c}35.8 \\
5.18 \\
3.40 \\
10.1\end{array}$ & $\begin{array}{c}11.3 \\
0 \\
0 \\
0\end{array}$ & $\begin{array}{l}0.233 \\
0.232 \\
0.232 \\
0\end{array}$ & $\begin{array}{l}3.02 \\
0.313 \\
0.313 \\
0\end{array}$ \\
\hline $\begin{array}{l}\text { Turbine: } \\
\text { Oil } \\
\text { Nat. gas }\end{array}$ & $\begin{array}{r}18 . \\
6.8\end{array}$ & $\begin{array}{l}148 \\
122\end{array}$ & $\begin{array}{l}89.0 \\
0.293\end{array}$ & $\begin{array}{l}20.1 \\
20.4\end{array}$ & $\begin{array}{l}55.5 \\
56\end{array}$ & $\begin{array}{l}0 \\
0\end{array}$ & $\begin{array}{l}0 \\
0\end{array}$ & $\begin{array}{l}0 \\
0\end{array}$ & $\begin{array}{l}0 \\
0\end{array}$ & $\begin{array}{l}0 \\
0\end{array}$ \\
\hline
\end{tabular}

*See footnote to Table 14

Table 16

NEP 1985 Emissions Matrix (short ton/10 $10^{2} \mathrm{Btu}$ )

\begin{tabular}{|c|c|c|c|c|c|c|c|c|c|c|}
\hline & Part & ${ }^{\text {No }} x$ & $\mathrm{SO}_{x}$ & $\mathrm{HC}$ & $\mathrm{CO}$ & Org & DS & Acid & $\begin{array}{c}\text { Th } \\
\left(10^{12} \mathrm{Btu}\right)\end{array}$ & SS \\
\hline \multicolumn{11}{|l|}{ Boller: } \\
\hline Coal & 41.2 & 356 & 811 & 6.15 & 20.5 & 0.909 & 31.5 & 8.60 & 0.176 & 2.29 \\
\hline Oil & 27.2 & 219 & 484 & 6.81 & 10.2 & 0.00720 & 4.75 & 0 & 0.176 & 0.237 \\
\hline Nat. gas & 4.85 & 139 & 0.293 & 0.485 & 8.25 & 0.00720 & 3.4 & 0 & 0.176 & 0.237 \\
\hline hood* & 1.66 & 232 & 4.98 & 119 & 99.7 & 0.00200 & 12.1 & 0 & 0 & 0 \\
\hline \multicolumn{11}{|l|}{ Turbine: } \\
\hline Oil & 18 & 139 & 84.4 & 20.1 & 55.5 & 0 & 0 & 0 & 0 & 0 \\
\hline Nat. gas & 6.80 & 107 & 0.293 & 20.4 & 56 & 0 & 0 & 0 & 0 & 0 \\
\hline
\end{tabular}

*See footnote to Table 14

Table 17

SF-2 1985 Emissions Matrix (short ton/10 $12 \mathrm{Btu}$ )

\begin{tabular}{|c|c|c|c|c|c|c|c|c|c|c|}
\hline & Part & $\mathrm{NO}_{\mathrm{x}}$ & $\mathrm{SO}_{\mathrm{x}}$ & $\mathrm{HC}$ & $\mathrm{CO}$ & Org & DS & Acid & $\begin{array}{c}\text { Th } \\
\left(1 \dot{0}^{12} \text { Btu }\right)\end{array}$ & SS \\
\hline \multicolumn{11}{|l|}{ Boiler: } \\
\hline Coal & 20.1 & 356 & 778 & 6.15 & 20.5 & 0.861 & 30.8 & 8.14 & 0.167 & 2.16 \\
\hline OiI & 27.2 & 215 & 475 & 6.81 & 10.2 & 0.00697 & 4.68 & 0 & 0.166 & 0.224 \\
\hline Nat. gas & 4.85 & 128 & 0.293 & 0.485 & 8.25 & 0.00697 & 3.40 & 0 & 0.166 & 0.224 \\
\hline fiood $*$ & 1.70 & 239 & 5.12 & 122 & 102 & 0.00206 & 12.4 & 0 & 0 & 0 \\
\hline \multicolumn{11}{|l|}{ Turbine: } \\
\hline $0 i 1$ & 18. & 127 & 83.5 & 20.1 & 55.5 & 0 & 0 & 0 & 0 & 0 \\
\hline Nat. gas & 6.80 & 104 & 0.293 & 20.4 & 56 & 0 & 0 & 0 & 0 & 0 \\
\hline
\end{tabular}

* See footnote to Table 14 
for the ath scenarlo, defined earlier, and $\mathrm{E}_{i}^{\mathrm{a}}$ be the fossil fuel breakdown of Table 6 (expressed in quads). Then, $P_{j}^{a}$, the emission intensity of pollutant $j$, is

$$
\left.P_{j}^{a}=10^{-6}\left[\left(\underset{i}{\stackrel{\Sigma}{\Sigma}} E_{i}^{a} e_{i j}^{a}\right) / E^{a}\right] \times 11,500 \text { (ton } / 10^{6} \mathrm{~kW}-\mathrm{hr}\right)
$$

where $E^{a}=\sum_{i} E_{i}^{a}$, and a heat rate of $11,500 \mathrm{Btu} / \mathrm{kW}$-hr has been assumed.

The data are presented in Table 18. Since the "controlled" emissions matrix applies to all scenarios in 2000 , variations over scenarios in that year are due to fuel mix differences. For 1985, the variations are functions not only of fuel mix but also of emission matrix, which depends on the fraction of central station fossil-fuel-driven plants that are "controlled." In some cases these factors counteract each other. For example, in 1985, SF-2 has a lower particulate emission.intensity than either A or B. This might seem surprising, since SF-2 incorporates a much more rapid shift to coal than do the CONAES scenarios; but this particulateincreasing factor is overridden by the high level of emissions control in SF-2 due to the assumption of rapid growth in electric1ty consumption.

\section{Total Emissions}

Total emissions are perhaps more revealing than emission intensities in weighing the environmental compatibility of the various scenarios. This is primarily because the large variation in fossil-fuel-derived electricity among the scenarios is due to different assumptions about end-use efficiencies and about the growth of nonconventional energy corversion technologies. None of the scenarios is based on quality of life curtailments. The scenarios embody differing concepts of the entire energy 


\begin{tabular}{|c|c|c|c|c|c|c|c|c|c|c|c|}
\hline & & & & & Tab1 & e 18 & & & & & \\
\hline & & Emission & Inter & nsities & by $S c$ & nario & (short to & $\operatorname{con} / 10^{6} \mathrm{k}$ & $k W-h r)$ & & \\
\hline Scena & rio & Part & ${ }^{\text {No }} \mathbf{x}$ & $\mathrm{so}_{\mathrm{x}}$ & $\mathrm{HC}$ & Co & Org & DS & Acid & $\begin{array}{c}\text { Th* } \\
\left(10^{9} \text { Btu }\right)\end{array}$ & SS \\
\hline BY & & 0.479 & 3.43 & 11.0 & 0.059 & 0.186 & 0.0122 & 20.310 & 0.116 & $6 \quad 4.57$ & 0.034 \\
\hline 1985: & $\begin{array}{l}\text { A } \\
\text { B } \\
\text { NEP } \\
S F-2\end{array}$ & $\begin{array}{l}0.426 \\
0.416 \\
0.430 \\
0.378\end{array}$ & $\begin{array}{l}3.40 \\
3.40 \\
3.74 \\
3.47\end{array}$ & $\begin{array}{l}8.79 \\
8.42 \\
8.25 \\
7.03\end{array}$ & $\begin{array}{l}0.064 \\
0.065 \\
0.082 \\
0.073\end{array}$ & $\begin{array}{l}0.196 \\
0.197 \\
0.241 \\
0.220\end{array}$ & $\begin{array}{l}0.0090 \\
0.0085 \\
0.0087 \\
0.0072\end{array}$ & $\begin{array}{ll}0.279 \\
5 & 0.272 \\
7 & 0.308 \\
2 & 0.268\end{array}$ & $\begin{array}{l}0.085 \\
0.080 \\
0.082 \\
0.068\end{array}$ & $\begin{array}{ll}2.84 \\
2.82 \\
2.62 \\
2 & 1.94 \\
8 & 1.86\end{array}$ & $\begin{array}{l}0.024 \\
0.022 \\
0.022 \\
0.019\end{array}$ \\
\hline $2000:$ & $\begin{array}{l}\text { A } \\
\text { B } \\
\text { NEP } \\
\text { SF-2 }\end{array}$ & $\begin{array}{l}0.253 \\
0.253 \\
0.234 \\
0.225\end{array}$ & $\begin{array}{l}3.47 \\
3.47 \\
3.81 \\
3.66\end{array}$ & $\begin{array}{l}2.60 \\
2.60 \\
2.28 \\
2.19\end{array}$ & $\begin{array}{l}0.075 \\
0.074 \\
0.127 \\
0.119\end{array}$ & $\begin{array}{l}0.217 \\
0.215 \\
0.280 \\
0.264\end{array}$ & $\begin{array}{l}3.42-5 \\
3.43-5 \\
3.37-5 \\
3.42-5\end{array}$ & $\begin{array}{ll}5 & 0.169 \\
5 & 0.169 \\
5 & 0.194 \\
5 & 0.185\end{array}$ & $\begin{array}{l}-- \\
-- \\
--\end{array}$ & $\begin{array}{l}-- \\
-- \\
-- \\
--\end{array}$ & $\begin{array}{l}-- \\
-- \\
-- \\
--\end{array}$ \\
\hline
\end{tabular}

Table 19

Total Utilfty Emissions ( $10^{6}$ short ton/yr)

\begin{tabular}{llllllllllll}
\hline Scenario & Part & NO $_{x}$ & SO $_{x}$ & HC & CO & Org & DS & Acid & $\begin{array}{c}\text { Th* } \\
\left(10^{9} \text { Btu }\right)\end{array}$ & SS \\
\hline BY & & 0.674 & 4.83 & 15.5 & 0.0836 & 0.261 & 0.0172 & 0.439 & 0.163 & 6.42 & 0.0474 \\
$1985:$ & A & 0.520 & 4.15 & 10.7 & 0.0787 & 0.240 & 0.0110 & 0.340 & 0.105 & 3.47 & 0.0296 \\
& B & 0.556 & 4.49 & 11.1 & 0.0860 & 0.260 & 0.0113 & 0.360 & 0.106 & 3.47 & 0.0300 \\
& NEP & 0.749 & 6.53 & 14.4 & 0.143 & 0.421 & 0.0151 & 0.536 & 0.143 & 3.38 & 0.0386 \\
& SF-2. & 0.698 & 6.41 & 13.0 & 0.135 & 0.406 & 0.0132 & 0.494 & 0.125 & 3.43 & 0.0344 \\
$2000:$ & A & 0.256 & 3.52 & 2.63 & 0.0756 & 0.219 & $3.46-5$ & 0.171 & -- & -- & -- \\
& B & 0.314 & 4.31 & 3.23 & 0.0922 & 0.267 & $4.26-5$ & 0.210 & -- & -- & -- \\
& NEP & 0.478 & 7.80 & 4.68 & 0.259 & 0.573 & $6.90-5$ & 0.398 & -- & -- & -- \\
& SF-2 & 0.478 & 7.77 & 4.64 & 0.252 & 0.559 & $7.26-5$ & 0.393 & -- & -- & -- \\
\hline *See Table 14 & & & & & & & & & $\cdots$ & \\
\hline
\end{tabular}


system, from resources to final consumption. Total emissions are related to the entire mix of fuel, technology, and efficiency and are not directly related to life-style changes.

The variation over the scenarios for the emission intensities was less than $25 \%$, but for total emissions it was as much as $100 \%$. The total emission of pollutant $j$ in the ath scenario can be written in terms of previously defined variables as

$$
10^{-3} \sum_{i} E_{i}^{a} e_{i j}^{a}\left(10^{6} \text { ton } / y r\right)
$$

The results are given in Table 19.

\section{RESIDENTIAL AND COMMERCIAL EMISSIONS}

\section{A. Energy Demands by Scenario}

Derivation of emissions in the residential-commercial sector involves specifying for each scenario the breakdown of fuel consumption by end use, dcsignating the approprlate emissions matrix, mapping fuel and end use into specific pollutant, and multiplying energy consumption sectors by the emissions matrices to arrive at final emissions. Unlike the industrial and utility sectors, where energy consumption was either explicitly indicated or could be deduced in a straightforward manner, the scenarios under consideration are highly underspecified in terms of total energy breakdown by end use and fuel mix. Before computing emissions, one must extract from existing studies the necessary disaggregation in final demands. In order to derive the residential and commercial energy consumption figures by fuel and by end use for each scenarto in future years, one must have an 
equivalent breakdown for the base year 1972. This breakdown should include dividing fuel oil into distillate oil, residual oil, and liquid petroleum gas (LPG), since the emission coefficient for each fuel is different in the two different sectors. Since the ERDA and CONAES scenarios are based on base years and fuel mixes somewhat different from those used here, the fuel mix by end use and sector for 1972 had to be reconstructed.

The ERDA scenarios were extrapolated from the 1972 numbers in the BNL Sourcebook, ${ }^{6}$ and these values were used as long as they were reasonably consistent with other data. A new data source not available when the BNL Sourcebook was compiled is the National Energy Accounts ${ }^{8}$ (NEA). This gives controlled totals for each fuel for each sector, and these were used for the residential sector, which is the more precisely defined of the two sectors. The gas total from NEA was slightly modified to match the gas data by end use from the Sourcebook. For both oil (distillate, residual, and LPG) and gas the totals for the residential and commercial sectors combined were taken from the Sourcebook.

All residual oil assigned by $\mathrm{NEA}$ to both the residential and commercial sectors was assumed to be used for space heat only, althougl. probably a sma1l percentage of it is used for hot water taken from a large boiler. Coal was assumed to be used only for commercial space heat, as in the Sourcebook. The values for distillate oil going to commercial space heat and for LPG in the commercial sector were taken from Hittman's data ${ }^{3}$ for 1970, the only available information about these quantities. The amount of distillate oil going to residential space heat was taken from the Sourcebook; when added to Hirst's r:umiter" for oil going to residential 
hot water, this gave the NEA value for total residential distillate oil. Distillate oll going to commerclal hot water was taken as the remainder. These results are summarized in Table 20. Note that here and throughout the study the data are disaggregated to three end uses: space heat (SH), water heat (WH) and cooking (C): In the residential and commercial sectors emissions are predominantly due to these uses, and those from other end uses are negligible. Emissions associated with the generation of electricity used for appliances and lighting have been charged to the utility sector, and those due to miscellaneous end uses (gas lights, natural-gas-driven airconditioners, etc.) are sma11. 3

From the base year fuel mix, the fraction of each fuel going to each sectoral end used was determined. These matrices are given in Table 21. Since the only information provided for future years in each scenario was the total oil or gas going to the joint residential and commercial sector, this matrix was used to obtain the fuel mix by end use for the future. Obviously, this involves the assumption that each fuel will be used for the same $\mathrm{mix}$ of end uses in the future as in 1972. No information was available by scenario regarding possible errors resulting from this assumption, and use of this assumption should not be taken to imply that for any given end use the fuel mix will remain the same.

Aggregated fuel breakdowns for each scenario are summarized in Table 22. The household and commercial floorspace assumptions underlying these projections are given in Table 23.* Assumptions on improvement of end-use efficiency for each scenario are presented in Table 24 in the form of

* These assumptions were not used in estimating residential-commercial energy use, but they are presented to show the relative importance of various measures aimed at conservation and improvement of end-use efficlency. 
Table 20

Base Year Commercial-Residential Fuel Use Breakdowns (quads)

\begin{tabular}{|c|c|c|c|c|c|c|c|c|c|}
\hline & \multicolumn{4}{|c|}{ Residential } & \multicolumn{4}{|c|}{ Commercial } & \multirow{2}{*}{$\begin{array}{l}\text { Grand } \\
\text { total }\end{array}$} \\
\hline & $\mathrm{SH}$ & $\mathrm{IH}$ & Cook & Total & $\mathrm{SH}$ & WH & Cook & Total & \\
\hline $\begin{array}{l}\text { Coal }{ }^{b} \\
\text { Res. oil } \\
\text { Dist. oil } \\
\text { Nat. gas }{ }^{b} \\
\text { LPG }\end{array}$ & $\begin{array}{l}0 \\
0.55 \mathrm{~b} \\
3.09^{\mathrm{b}} \\
3.82 \mathrm{f} \\
0.07^{\mathrm{f}}\end{array}$ & $\begin{array}{l}0 \\
0 \\
0.27^{d} \\
1.18 \\
0.12^{b}\end{array}$ & $\begin{array}{l}0 \\
0 \\
0 \\
0.30 \\
0.06^{b}\end{array}$ & $\begin{array}{l}0 \\
0.55 \\
3.36^{c} \\
5.30 \\
0.25^{c}\end{array}$ & $\begin{array}{l}0.32 \\
0.55 \\
0.57^{\mathrm{e}} \\
1.56 \\
0.08 \mathrm{e}\end{array}$ & $\begin{array}{l}0 \\
0 \\
0.20^{f} \\
0.44 \\
0.02\end{array}$ & $\begin{array}{l}0 \\
0 \\
0 \\
0.13 \\
0.01\end{array}$ & $\begin{array}{l}0.32 \\
0.55 \mathrm{f} \\
0.77^{\mathrm{f}} \\
2.13 \mathrm{e} \\
0.11\end{array}$ & $\begin{array}{l}0.32 \\
1.10 \\
4.13 \\
7.43 \\
0.36\end{array}$ \\
\hline
\end{tabular}

${ }^{a}$ Grand totals for coal, oll (residual, distillate, and LPG), and natural gas agree with data in $r \in f .6$.

${ }^{b}$ see ref. 6. $\quad c_{\text {See ref. 8. }}$ see ref. 9. ${ }^{d}$ See ref. 3.

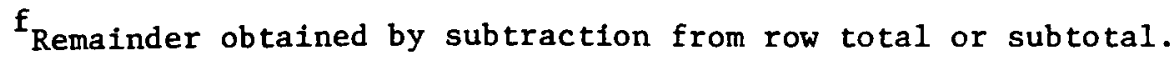

Table 21

Fractional Distributions of Fuel

\begin{tabular}{|c|c|c|c|c|c|c|c|}
\hline & & \multicolumn{3}{|c|}{ Residential } & \multicolumn{3}{|c|}{ Commercial } \\
\hline & & SH & ẈH & Cook & SH & WH & Cook \\
\hline \multirow[t]{3}{*}{ Oil: } & Res & 0.098 & 0 & 0 & 0.098 & 0 & 0 \\
\hline & Dist & 0.553 & 0.048 & 0 & 0.102 & 0.036 & 0 \\
\hline & LPG & 0.013 & 0.021 & 0.011 & 0.014 & 0.004 & 0.002 \\
\hline $\begin{array}{l}\text { Nat. } \\
\text { Coal }\end{array}$ & gas & 0.514 & 0.158 & 0.040 & $\begin{array}{l}0.209 \\
1.0\end{array}$ & 0.059 & 0.017 \\
\hline
\end{tabular}

Table 22

Aggregate Fuel Mix by Scenario (quads)

\begin{tabular}{|c|c|c|c|c|c|c|c|c|c|}
\hline \multirow[b]{2}{*}{ Fue1 } & \multirow[b]{2}{*}{1972} & \multicolumn{2}{|c|}{ A } & \multicolumn{2}{|c|}{ B } & \multicolumn{2}{|c|}{ NEP } & \multicolumn{2}{|c|}{$S F=2$} \\
\hline & & 1985 & 2000 & 1985 & 2000 & 1985 & 2000 & 1985 & 2000 \\
\hline $\begin{array}{l}\text { Oil } \\
\text { Nat. gas } \\
\text { Coal }\end{array}$ & $\begin{array}{l}5.6 \\
7.4 \\
0.3\end{array}$ & $\begin{array}{l}3.3 \\
6.4 \\
0.2\end{array}$ & $\begin{array}{l}1.8 \\
4.8 \\
0\end{array}$ & $\begin{array}{l}3.8 \\
6.6 \\
0.3\end{array}$ & $\begin{array}{l}3.6 \\
4.3 \\
0.3\end{array}$ & $\begin{array}{l}5.0 \\
7.8 \\
0.11\end{array}$ & $\begin{array}{l}2.5 \\
6.7 \\
0\end{array}$ & $\begin{array}{l}6.9 \\
8.1 \\
0\end{array}$ & $\begin{array}{l}4.6 \\
7.2 \\
0\end{array}$ \\
\hline
\end{tabular}


Table 23

Household and Commercial Floorspace Assumptions

\begin{tabular}{|c|c|c|c|c|c|c|c|c|}
\hline \multirow{2}{*}{. } & \multicolumn{4}{|c|}{1985} & \multicolumn{4}{|c|}{2000} \\
\hline & A & B & NEP & $\mathrm{SF}-2$ & A & B & NEP & $S F-2$ \\
\hline \multicolumn{9}{|l|}{ Households $\left(10^{6}\right)$} \\
\hline $\begin{array}{l}\text { Single-family } \\
\text { Multifamily }\end{array}$ & $\begin{array}{l}59.0 \\
26.7\end{array}$ & $\begin{array}{l}59.0 \\
26.7\end{array}$ & $\begin{array}{l}52.4 \\
31.8\end{array}$ & $\begin{array}{l}52.4 \\
31.8\end{array}$ & $\begin{array}{l}71.5 \\
34.6\end{array}$ & $\begin{array}{l}71.5 \\
34.6\end{array}$ & $\begin{array}{l}63.8 \\
38.0\end{array}$ & $\begin{array}{l}63.8 \\
38.0\end{array}$ \\
\hline Total & 85.7 & 85.7 & 84.2 & 84.2 & 106.1 & 106.1 & 101.8 & 101.8 \\
\hline Commercial $\left(10^{9} \mathrm{ft}^{2}\right)$ & 32.3 & 32.3 & 32.9 & 32.9 & 40.5 & .40 .5 & 43.5 & 43.5 \\
\hline Real GNP growth $(\% / y r)$ & 2.15 & 2.15 & 3.1 & 3.1 & 2.15 & 2.15 & 3.1 & 3.1 \\
\hline
\end{tabular}

Table 24

End-Use Energy Intensities* (1.0 in 1972)

\begin{tabular}{|c|c|c|c|c|c|c|c|c|}
\hline & \multicolumn{4}{|c|}{1985} & \multicolumn{4}{|c|}{2000} \\
\hline & A & B & NEP & $S F-2$ & A & B & NEP & $S F-2$ \\
\hline SIl gas & 0.88 & 0.85 & 0.83 & 0.91 & 0.67 & 0.70 & 0.64 & 0.81 \\
\hline SH ofl & 0.88 & 0.87 & 0.85 & 0.92 & 0.67 & 0.75 & 0.64 & 0.81 \\
\hline WH gas & 0.70 & 0.73 & 0.87 & 0.96 & 0.65 & 0.70 & 0.84 & 0.96 \\
\hline WH oil & 0.70 & 0.73 & 1.0 & 1.0 & 0.65 & 0.70 & 1.0 & 1.0 \\
\hline Cook gas & 0.66 & 0.66 & 0.87 & 0.96 & 0.65 & 0.65 & 0.84 & 0.96 \\
\hline
\end{tabular}

*Data from ref. 7 and BNL RES's. Intensity is a measure of total energy use in comparison with that in a base year. 
relative energy intensities for relevant end uses, if avallable. Combining the fractional distribution of fuel (matrices in Table 21) with the aggregate fuel breakdowns (Table 22) leads to the disaggregated energy use distributions listed in Tables 25 and 26 . These energy allotments are used below, in combination with the residential and comercial emission matrices, to evaluate emissions by pollutants, end use, and sector.

\section{B. Emission Coefficients}

Since water-borne emissions from energy use in the commercial and residential sectors are negligible, the analysis is limited to the five air pollutants 1isted in Table 7. The first step is to compute the emissions matrix for commercial and residential boilers. The Environmental Protection Agency $^{2}$ (EPA) has compiled emission factors as a function of physical unit of fuel input (see Tables 27 and 28). The ratings range from "a" (highest confidence) to "c" (average).

In order to develop matrices of emission as a function of energy input, one must specify the average fuel content for each resource. The values used in this study, along with average sulfur and ash content assumptions, are given in Table 29. With these values, conversion of the data in Tables 27 and 28 into boiler emission matrices, expressed as short tons of pollutant per $10^{12}$ Btu input, is straightforward. These matrices are given in Tables 30 and 31 , and discrepancies with Hittman data ${ }^{3}$ are indicated. As in the utility sector, the discrepancies are presumably due either to computational errors or to Hittmar's using earlier EPA emissions data. Note that the breakdown of coal fuel resource usage in the commercial sector of 







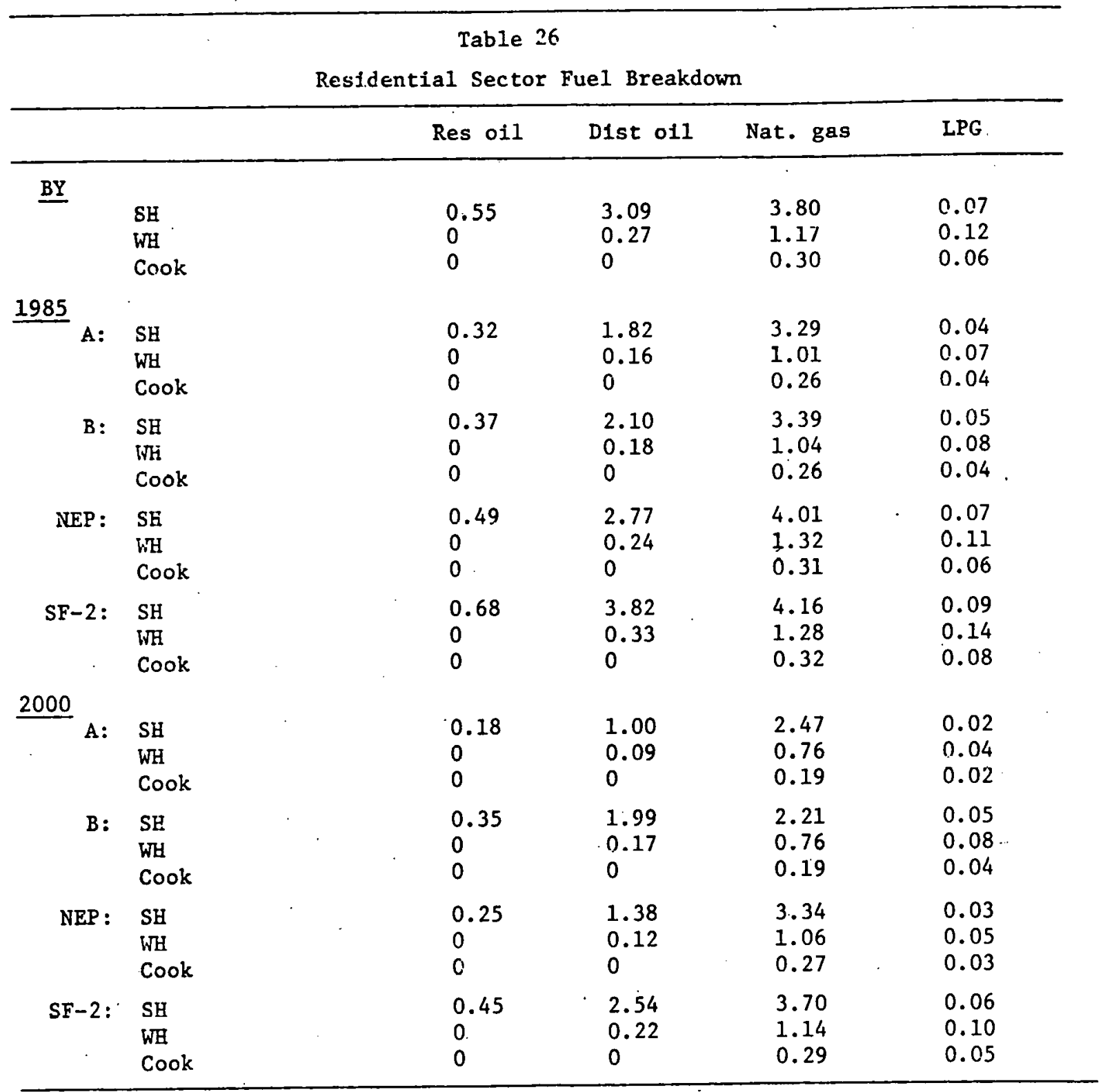


Table 27

Boller Emission Factors, Commercial Sector

(1t/physical fuel unit) (from ref. 2)

\begin{tabular}{|c|c|c|c|c|c|c|c|c|}
\hline Fue1 & Unj & & Part* & $\mathrm{SO}_{x} \star \star \star$ & No $_{x}$ & $\mathrm{HC}$ & $\mathrm{CO}$ & Rating \\
\hline Bit coal & & ton & $2 \mathrm{~A}$ & 385 & 6 & 3 & 10 & $\mathbf{a}$ \\
\hline Anth coal & & ton & $2 \mathrm{~A}$ & $38 \mathrm{~S}$ & 6 & 0.2 & 10 & $\mathrm{~b}$ \\
\hline Res cill & $10^{3}$ & gal & 23 & $159 \mathrm{~S}$ & 60 & 3 & 4 & $\mathbf{a}$ \\
\hline Dist oil & $10^{3}$ & gal & 15 & $144 \mathrm{~S}$ & 60 & 3 & 4 & a \\
\hline Nat. gas & $10^{6}$ & $\mathrm{ft}^{3}$ & 10 & 0.6 & 120 & 8 & 20 & a \\
\hline LPG & $10^{3}$ & gal & 1.9 & $0.09 \mathrm{~s}$ & 12 & 0.8 & 2.0 & c \\
\hline
\end{tabular}

$\star A=w t \%$ of ash in coal.

$* * S=w t \%$ of sulfur for coal and oil, and grains/100 $\mathrm{ft}^{3}$ gas vapor for LPG.

Average sulfur content of natural gas is taken as 2000 grains $/ 10^{6} \mathrm{std}_{\mathrm{ft}} \mathrm{f}^{\text {. }}$




Table 30

Boiler Enission Matrix, Commerclal Sector (short ton $/ 10^{12}$ Btu)

\begin{tabular}{lccccc}
\hline Fuel & Part & No & so $_{x}$ & HC & CO \\
\hline Coa1* & 429 & 122 & 1270 & 46.3 & 204 \\
Res o11 & 77.2 & 201 & $923 * *$ & 10.1 & $13.5 * *$ \\
D18t o11 & 54.3 & 217 & 114 & 10.9 & $14.5 * *$ \\
Nat. 8a8 & $4.85 * *$ & $58.2 * *$ & 0.291 & 3.88 & 9.70 \\
LPG & 9.96 & $62.9 * *$ & 5.66 & 4.19 & 10.5 \\
\hline
\end{tabular}

*Assumes mix of $27 \%$ anthracite and $73 \%$ bltuminous by fuel value (see ref. 10 ). **Discrepancy with data in ref. 3 .

Table 31

Boller Bmiseion Matrix, Residential Sector (short ton $/ 10^{22} \mathrm{Btu}$ )

\begin{tabular}{|c|c|c|c|c|c|}
\hline Fuel & Part & $\mathrm{NO}_{x}$ & so $_{x}$ & Bac & co \\
\hline $\begin{array}{l}\text { Res o11 } \\
\text { Diet ofl } \\
\text { Nat gas } \\
\text { LPG }\end{array}$ & $\begin{array}{l}77.2 \\
36.2 \\
4.85 * \\
9.96 * \hbar\end{array}$ & $\begin{array}{l}40 * \\
43.5 \\
38.8 * k \\
41.9 * k\end{array}$ & $\begin{array}{l}923 \\
114 \\
0.291 \text { k* } \\
5.66 k k\end{array}$ & $\begin{array}{c}10.1 \\
10.9 \\
3.88 \\
4.19 \hbar\end{array}$ & $\begin{array}{c}13.5 \\
18.1 \\
9.70 \\
10.5\end{array}$ \\
\hline
\end{tabular}

*N1trogen oxides emission for oll-fired residentlal bollers 18 not given separately in ref. 2, The value given here was derived from the proportion

Resident1al restdual o11 Na factor - Residentlal dist11late o11 NOx factor. Commerctal residual oll $\mathrm{NO}_{\mathrm{x}}$ factor Commerctal distlliate oll No $\mathrm{xactor}$ **Discrepancy with data In ref. 3.

Table 32

Emlosion Matrix Correction Factors (from ref, 3)

\begin{tabular}{lrccccc} 
& Part & NO & SO & HC & CO \\
\hline Commercial: & WH & 1.0 & 1.1 & 1.0 & 1.1 & 1.0 \\
& C & 1.0 & 0.6 & 1.0 & 1.0 & 1.0 \\
Resident1al: WH & 1.0 & 0.6 & 1.0 & 1.0 & 1.0 \\
& C & 1.0 & 0.5 & 1.0 & 1.0 & 1.0 \\
\hline
\end{tabular}


$27 \%$ anthracite and $73 \%$ bituminous reported by the Bureau of Mines ${ }^{10}$ is assumed to persist through the time frame of the study.

The final step is to extend the boiler emission matrices applicable for space heating to the other end uses. The correction factors used are given in Table 32.

C. Emission by End Use

The evaluation of emissions associated with specific end uses is a straightforward exercise in matrix multiplication. The nomenclature and equations presented in Tables 33 and 34 provied the basis for a computer program to evaluate $\mathrm{P}_{\mathrm{kj}}^{\mathrm{a}}$, emission as a function of end use and scenario. The results are presented in Tables 35 and 36 .

Variations in emission levels among the scenarios are due to different assumptions about the aggregate amount of fuel consumed and the fuel mix for each end use. In some cases these effects counteract each other, for instance, the ERDA scenarios lead to less particulate emissions from space heating than do the conAEs scenario despite their higher fuel ise levels because the CONAES scenarios assume more coal consumption in the commercial sector. The data in Tables 35 and 36 show that emissions vary widely and are sensitive functions of both the kinds and the total amounts of fuel assumed.

D. Total Emissions

Total emissions for each scenario are presented in Tables 37 and 38 for the commercial and residential sectors, and these have been summed to give the total commercial-residential. sector emissions shown in Table 39 . 
Table 33

Computational Procedure for Commercial End-Use Emissions

Let:

eij = commercial sector emissions matrix (Table 30) in tons pollutant $/ 10^{12}$ Btu

$E_{k 1}^{a}=$ consumption of fuel $i$ (in quads/yr) by end-use $k$ in scenario a (Table 25) $\mathrm{P}_{\mathrm{kj}}^{\mathrm{a}}=\underset{\mathrm{k} \text { in scenario } \mathrm{a}}{\text { emission (in } 10^{6} \text { ton/yr) of pollutant } \mathrm{j} \text { due to end-use }}$

Then:

$$
P_{j k}^{a}=10^{-3} \quad \sum_{i} E_{k i}^{a} e i j
$$

Definitions of Variables:

\begin{tabular}{lllll} 
& \multicolumn{1}{c}{$\mathrm{i}$} & \multicolumn{1}{c}{$\mathrm{j}$} & \multicolumn{1}{c}{$\mathrm{a}$} \\
1 & Coal & Part & SH & Base year \\
2 & Res o11 & $\mathrm{NO}_{\mathbf{X}}$ & WH & A 1985 \\
3 & Dist oil & $\mathrm{SO}_{\mathbf{X}}$ & C & B1985 \\
4 & Nat. gas & HC & -- & NEP 1985 \\
5 & LPG & CO & -- & SF-2 1985 \\
6 & -- & -- & -- & A 2000 \\
7 & -- & -- & -- & B 2000 \\
8 & -- & -- & -- & NEP 2000 \\
9 & -- & -- & -- & SF-2 2000
\end{tabular}

Table 34

Computational Procedure for Residential Enc-Use Emissions

Let:

eij = residential sector emissions (Table 31 ) in tons pollutant $/ 10^{12}$ Btu

$E_{k i}^{a}=$ consumption of fuel $i$ (in quads/yr) by end-use $k$ in scenario a (Table 26)

$\mathrm{P}_{\mathrm{kj}}^{\mathrm{a}}=$ emission (in $10^{6}$ ton/yr) of pollutant $\mathrm{j}$ due to end-use

Then:

$$
P_{k j}^{a}=10^{-3} \quad \sum_{i} E_{k i}^{a} \text { eij }
$$

Definftions of Variables:

j $\quad k$

a

1 Res o11

Dist oil

Nat. gas

LPG HC -. NEP 1985

Part SH Base year

$\mathrm{NO}_{\mathbf{X}} \quad$ WH $\quad$ A 1985

$\mathrm{SO}_{\mathbf{X}} \quad \mathrm{C} \quad$ B 1985

-- $\quad$ CO $\quad--\quad$ SF-2 1985

$\begin{array}{lllll}- & - & - & & \text { A } 2000\end{array}$

$--\quad--\quad-\therefore \quad$ B 2000

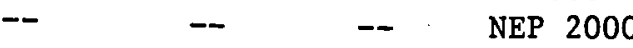

- $\quad$-- $\quad-\quad$ SF-2 2000


Table 35

Emissions by End-Use, Commercial Sector ( $10^{6}$ short ton/yr)

\begin{tabular}{|c|c|c|c|c|c|c|c|}
\hline & & & Part & $\mathrm{NO}_{\mathbf{x}}$ & $\mathrm{SO}_{\mathrm{x}}$ & $\mathrm{HC}$ & $\mathrm{CO}$ \\
\hline \multicolumn{8}{|l|}{ BY } \\
\hline & SH. & & $2.10-1 *$ & $3.67-1$ & $9.55-1$ & $3.20-2$ & $9.28-2$ \\
\hline & WH & & $1.32-2$ & $7.73-2$ & $2.30-2$ & $3.97-3$ & $7.38-3$ \\
\hline & C & & $7 \cdot 30-4$ & $4.92-3$ & $9.44-5$ & $5.46-4$ & $1.37-3$ \\
\hline \multicolumn{8}{|l|}{1985} \\
\hline A : & SH & & 1. $36-1$ & $2.43-1$ & $5.89-1$ & $2.16-2$ & $6.34-2$ \\
\hline & WH & . & $8.46-3$ & $5.37-2$ & $1.38-2$ & $2.82-3$ & $5.53-3$ \\
\hline & $\mathrm{C}$ & . & $6.33-4$ & $4.22-3$ & $8.86-5$ & $4.69-4$ & $1.17-3$ \\
\hline B: & SH & & $1.86-1$ & $2.79-1$ & $7.68-1$ & $2.74-2$ & $8.58-2$ \\
\hline - & WH & & $9.69-3$ & $5.98-2$ & $1.62-2$ & $3.12-3$. & $6.02-3$ \\
\hline & $\mathrm{C}$ & & $6 \cdot 33-4$ & $4.22-3$ & $8.86-5$ & $4.69-4$ & $1.17-3$ \\
\hline NEP : & $\mathrm{SH}$ & & $1.21-1$ & 3. 22-1 & $6.5 I-1$ & $2.22-2$ & $5.30-2$ \\
\hline & WH & & $1.22-2$ & $7.38-2$ & $2.08-2$ & $3.83-3$ & $7.28-3$ \\
\hline & &. & $7.30-4$ & $4.92-3$ & $9.44-5$ & $5.46-4$ & $1.37-3$ \\
\hline$S F-2:$ & SH & & $9.97-2$ & $3.93-1$ & $7.08-1$ & $2.14-2$ & $3.68-2$ \\
\hline & WH & & $1.62-2$ & $9.25-2$ & $2.88-2$ & $4.71-3$ & $8.60-3$ \\
\hline & $\mathrm{C}$ & & $7.79-4$ & $5.27-3$ & $9.73-5$ & $5.85-4$ & $1.46-3$ \\
\hline \multicolumn{8}{|l|}{2000} \\
\hline A: & SH & & $2.88-2$ & $1.35-1$ & $1.87-1$ & $7.78-3$ & 1. $51-2$ \\
\hline & WH & & $5.26-3$ & $3.53-2$ & $8.12-3$ & $1.89-3$ & $3.84-3$ \\
\hline r. & $\mathrm{C}$ & & $3.88-4$ & $2.79-3$ & $2.33-5$ & $3.10-4$ & $7.76-4$ \\
\hline \multirow[t]{3}{*}{ B : } & $\mathrm{SH}$ & & $1.81-1$ & $2.43-1$ & $7.55-1$ & $2.52-2$ & $8.06-2$ \\
\hline & W.: & & $9: 01-3$ & $5.08-2$ & $1.61-2$ & $2.58-3$ & $4.67-3$ \\
\hline & $\mathrm{C}$ & & $4.39-4$ & $2.82-3$ & $7.70-5$ & $3.14-4$ & $7.84-4$ \\
\hline \multirow[t]{3}{*}{ NEP : } & SḤ & & $4.06-2$ & $1.90-1$ & $2.60-1$ & $1.10-2$ & $2.11-2$ \\
\hline & WH & & $6.93-3$ & $4.78-2$ & $1.04-2$ & $2.57-3$ & $5.29-3$ \\
\hline & $\mathrm{C}$ & & $6.33-4$ & $4.21-3$ & $8.86-5$ & $4.69-4$ & $1.17-3$ \\
\hline \multirow[t]{3}{*}{$S F-2:$} & $\mathrm{SH}$ & & $6.82-2$ & $2.84-1$ & $4.70-1$ & $1.58-2$ & $2.82-2$ \\
\hline & WH & & $1.15-2$ & $6.95-2$ & $1.96-2$ & $3.60-3$ & $6.85-3$ \\
\hline & $\mathrm{C}$ & & $6.82-4$ & $4.57-3$ & $9.15-5$ & $5.08-4$ & $1.27-3$ \\
\hline
\end{tabular}

*This is computer notation for $10^{-1}$. 


\begin{tabular}{|c|c|c|c|c|c|c|}
\hline \multicolumn{7}{|c|}{ Table 36} \\
\hline \multicolumn{2}{|c|}{ Emissions by } & \multicolumn{5}{|c|}{ End-Use, Residential Sector $\left(10^{6}\right.$ short ton/yr) } \\
\hline & & Part & ${ }^{N O} x$ & ${ }^{\text {SO }_{x}}$ & $\mathrm{HC}$ & $\mathrm{CO}$ \\
\hline \multicolumn{7}{|l|}{$\underline{\mathrm{BY}}$} \\
\hline & SH & $1.73-1 *$ & $3.06-1$ & $8.61-1$ & $5.43-2$ & $1.01-1$. \\
\hline & WH & $1.66-2$ & $3.73-2$ & $3.18-2$ & $7.99-3$ & $1.75-2$ \\
\hline & $\mathrm{C}$ & $2.05-3$ & $7.08-3$ & $4.27-4$ & $1.42-3$ & $3.54-3$ \\
\hline \multicolumn{7}{|l|}{1985} \\
\hline A: & $\mathrm{SH}$ & $1.07-1$ & $2.21-1$ & $5.04-1$ & $3.60-2$ & $6.96-2$ \\
\hline & WH & $1.14-2$ & $2.94-2$ & $1.89-2$ & $5.96-3$ & $1.34-2$ \\
\hline & C & $1.66-3$ & $5.88-3$ & $3.02-4$ & $1.18-3$ & $2.94-3$ \\
\hline \multirow[t]{3}{*}{ B : } & $\mathrm{SH}$ & $1.22-1$ & $2.40-1$ & $5.82-1$ & $4.00-2$ & $7.64-2$ \\
\hline & WH & 1. $24-2$ & $3.09-2$ & $2.13-2$ & $6.33-3$ & $1.42-2$ \\
\hline & $\mathrm{C}$ & $1.66-3$ & $5.88-3$ & $3.02-4$ & $1.17-3$ & $2.94-3$ \\
\hline \multirow[t]{3}{*}{ NEP: } & $\mathrm{SH}$ & $1.58-1$ & $2.99-1$ & $7.70-1$ & $5.10-2$ & $9.64-2$ \\
\hline & WH & $1.62-2$ & $3.98-2$ & $2.84-2$ & $8.20-3$ & $1.83-2$ \\
\hline & $\mathrm{C}$ & $2.10-3$ & $7.27-3$ & $4.30-4$ & $1.45-3$ & $3.64-3$ \\
\hline \multirow[t]{3}{*}{$S F-2:$} & $\mathrm{SH}$ & $2.12-1$ & $3.59-1$ & 1.06 & $6.50-2$ & $1.19-1$ \\
\hline & WH & $1.95-2$ & $4.19-2$ & $3.88-2$ & $9.15-3$ & $1.99-2$ \\
\hline & $\mathrm{C}$ & $2.35-3$ & $7.88-3$ & $5.46-4$ & $1.58-3$ & $3.94-3$ \\
\hline \multicolumn{7}{|l|}{2000} \\
\hline \multirow[t]{3}{*}{ A: } & $\mathrm{SH}$ & $6.23-2$ & $1.47-1$ & $2.81-1$ & $2.24-2$ & $4.47-3$ \\
\hline & WH & $7.34-3$ & $2.10-2$ & $1.07-2$ & $4 \cdot 10-3$ & $9.42-3$ \\
\hline & $C$ & $1.12-3$ & $4.10-3$ & $1.69-4$ & $8.21-4$ & $2.05-3$ \\
\hline \multirow[t]{3}{*}{ B : } & $\mathrm{SH}$ & $1.10-1$ & $1.88-1$ & $5.51-1$ & $3.40-2$ & $6-27-2$ \\
\hline & WE & $1.06-2$ & $2.41-2$ & $2.01-2$ & $5.14-3$ & $1.13-2$ \\
\hline & $c$ & $1.32-3$ & $4.52-3$ & $2.82-4$ & $9.05-4$ & $2.26-3$ \\
\hline \multirow[t]{3}{*}{ NEP: } & $\mathrm{SH}$ & $8.62-2$ & $2.05-1$ & $3.89-1$ & $3.10-2$ & $6.20-2$ \\
\hline & WH & $9.98-3$ & $2.91-2$ & $1.43-2$ & $5.63-3$ & $1.30-2$ \\
\hline & $C$ & $1.61-3$ & $5.87-3$ & $2.48-4$ & $1.17-3$ & $2.93-3$ \\
\hline \multirow[t]{3}{*}{$S F-2:$} & $\mathrm{SH}$ & $1.45-1$ & $2.75-1$ & $7.06-1$ & $4.68-2$ & $8.86-2$ \\
\hline & WH & $1.45-2$ & $3.48-2$ & $2.60-2$ & $7.24-3$ & $1.61-2$ \\
\hline & $\mathrm{C}$ & $1.90-3$ & $6.67-3$ & $2.67-4$ & $1.33-3$ & $3.34-3$ \\
\hline
\end{tabular}

* See footnote to Table 25. 
Table 37

Commercial Emission Totals $\left(10^{6}\right.$ short ton/yr)

\begin{tabular}{lllllll}
\hline & & Part & NO & SO & HC & CO \\
\hline BY & & $2.24-1 \star$ & $4.49-1$ & $9.78-1$ & $3.66-2$ & $1.01-1$ \\
$1985:$ & A & $1.45-1$ & $3.01-1$ & $6.03-1$ & $2.49-2$ & $7.02-2$ \\
& B & $1.96-1$ & $3.43-1$ & $7.84-1$ & $3.10-2$ & $9.30-2$ \\
& NEP & $1.34-1$ & $4.01-1$ & $6.72-1$ & $2.66-2$ & $6.16-2$ \\
& SF-2 & $1.17-1$ & $4.91-1$ & $7.37-1$ & $2.68-2$ & $4.68-2$ \\
$2000:$ & A & $3.45-2$ & $1.73-1$ & $1.95-1$ & $9.99-3$ & $1.97-2$ \\
& B & $1.90-1$ & $2.97-1$ & $7.71-1$ & $2.81-2$ & $8.6 C-2$ \\
& NEP & $4.82-2$ & $2.43-1$ & $2.72-1$ & $1.40-2$ & $2.76-2$ \\
& SF-2 & $8.03-2$ & $3.58-1$ & $4.89-1$ & $1.99-2$ & $3.63-2$ \\
\hline
\end{tabular}

*See footnote to Table 35 .

Table 38

Residential Emission Totals $\left(10^{6}\right.$ short ton/yr) ;

\begin{tabular}{llccccc}
\hline & & Part & NO & SO & HC & CO \\
\hline BY & & $1.92-1 *$ & $3.51-1$ & $8.94-1$ & $6.37-2$ & $1.22-1$ \\
$1985:$ & A & $1.20-1$ & $2.57-1$ & $5.23-1$ & $4.31-2$ & $8.60-2$ \\
& B & $1.36-1$ & $2.77-1$ & $6.04-1$ & $4.75-2$ & $9.35-2$ \\
& NEP & $1.77-1$ & $3.46-1$ & $7.98-1$ & $6.06-2$ & $1.18-1$ \\
& SF-2 & $2.34-1$ & $4.08-1$ & 1.10 & $7.58-2$ & $1.43-1$ \\
2000: & A & $7.07-2$ & $1.73-1$ & $2.92-1$ & $2.73-2$ & $5.62-2$ \\
& B & $1.22-1$ & $2.17-1$ & $5.71-1$ & $4.01-2$ & $7.63-2$ \\
& NEP & $9.78-2$ & $2.40-1$ & $4.04-1$ & $3.78-2$ & $7.79-2$ \\
& SF-2 & $1.61-1$ & $3.16-1$ & $7.33-1$ & $5.54-2$ & $1.08-1$ \\
\hline
\end{tabular}

*See footnote to Table 35 .

Table 39

Total Commercial-Residential Emissions ( $10^{6}$ short ton/yr)

\begin{tabular}{lllllll}
\hline & & \multicolumn{2}{c}{ Part } & \multicolumn{2}{c}{ NO $_{x}$} & \multicolumn{2}{c}{ SO $_{x}$} & HC & CO \\
\hline BY & & $4.16-1 *$ & $8.00-1$ & 1.87 & $1.00-1$ & $2.23-1$ \\
$1985:$ & A & $2.65-1$ & $5.58-1$ & 1.13 & $6.80-2$ & $1.56-1$ \\
& B & $3.32-1$ & $6.20-1$ & 1.39 & $7.85-2$ & $1.87-1$ \\
& NEP & $3.11-1$ & $7.47-1$ & 1.47 & $8.72-2$ & $1.80-1$ \\
& SF-2 & $3.51-1$ & $8.99-1$ & 1.84 & $1.03-1$ & $1.90-1$ \\
$2000:$ & A & $1.05-1$ & $3.46-1$ & 0.312 & $3.73-2$ & $7.59-2$ \\
& B & $3.12-1$ & $5.14-1$ & 1.34 & $6.82-2$ & $1.62-1$ \\
& NEP & $1.46-1$ & $4.83-1$ & 0.676 & $5.18-2$ & $1.05-1$ \\
& SF-2 & $2.41-1$ & $6.74-1$ & 1.22 & $7.53-2$ & $1.44-1$ \\
\hline
\end{tabular}

* See footriote to Table 35 . 
1. The Effect on Air and Water Emissions of Energy Conservation in Industry, Energy Systems Research Group, Inc., Final Report, submitted Sept. 1977, BNL 50815.

2. Compilation of Air Pollutant Emission Factors, 2nd ed., EPA, * Feb. 1976.

3. Environmental Impacts, Efficiency and Cost of Energy Supply and End-Use, Vol. 1, Hittman Associates, Inc., Nov. 1974.

4. Standards of Performance for New Stationary Sources, EPA, Federal Register, Dec. 23, 1971.

5. Draft Standards Support and Environmental Impact Statement, Vo1. I, Proposed Standards of Performance for Stationary Gas Turbines, EPA, April 1977.

6. Sourcebook for Energy Assessment, M. Beller, Editor, BNL 50483, Dec. 1975.

7. Outlook for Energy Demand and Conservation (Draft), CONAES Panel on Demand and Conservation, Dec. 1976.

8. National Energy Accounts: Energy Flows in the U.S. 1971, Jack Faucett Associates, for Federal Energy Administration, Nov. 1971.

9. Eric Hirst, An Engineering-Economic Model of Residential Energy Use, Oak Ridge Nat. Lab. Rep. ORNL/TM 5470, July 1976.

10. Minerals Yearbook, U.S. Bureau of Mines, 1972.

\footnotetext{
${ }^{\star}$ EPA $=$ U.S. Environmental Protection Agency.
} 